Editorial

\title{
Sacred Journeys: Religious Tourism and Pilgrimage
}

\author{
Chadwick Co Sy Su \\ Department of Arts and Communication, University of the Philippines Manila, Padre Faura Street, \\ Metro Manila 1000, Philippines; ccsysu@up.edu.ph
}

Received: 31 July 2018; Accepted: 27 August 2018; Published: 29 August 2018

Keywords: shrines; peace pilgrimage; planetary consciousness; autoethnography; Buddhism; self-discovery; thanatology; ethics; living will; sacred space; walking meditation; mindfulness

\section{Introduction}

Pilgrimage, being an ancient practice and a global phenomenon, continues to gain a growing interest among scholars as its scope traverses many other disciplines and perspectives. As pilgrimage becomes a thriving category of tourism globally, it is deemed appropriate to look into it using different lenses including those of Islam, Hinduism, Buddhism, Christianity, Judaism, Taoism, and other traditions such as the secular one. This body of work is seen to be a worthwhile addition to John Eade, Ian Reader and Ellen Badone's series of studies on religion, travel and tourism. This Special Issue integrates published papers from the 4th Sacred Journeys Global Conference held at the Indiana University Gateway in Beijing, China on 26 and 27 October 2017, where the personal, interpersonal, intercultural, international, and comparative aspects of pilgrimage, among others, were brought to light.

Several approaches were used in this edition to examine pilgrimage by illustrating how it sits at the junction of the human and inhuman, lived experiences and beyond death, physical and metaphysical, the past and present, the academic and practical, as well as grief and memory. "The Return to the Sacred: The Shrine of Our Lady of Walsingham and Contemporary Christianity" by Susan Dunn-Hensley, argues the importance of both physical and spiritual manifestations of the sacred. Roy Tamashiro's "Planetary Consciousness, Witnessing the Inhuman, and Transformative Learning: Insights from Peace Pilgrimage Oral Histories and Autoethnographies" focuses on the attempt to achieve healing through getting in touch with the human and inhuman, and achieving one's peace by accepting the reality of both. "Heading to Chaityabhoomi: Pilgrimages of Remembrance" by Anna Bochkovskaya on the other hand, presents pilgrimages as a way and process of transforming grief and sorrow into gratitude and commemoration, and, in the Dalits' sense, of memorializing not just Chaityabhoomi but also their triumphant history over subservience.

Pilgrimage was then presented from the walls of academia and beyond in the "Experiencing and Teaching Pilgrimage in a Sacred Spaces Course" by Thomas J. Sienkewicz, where rediscovering and reconnecting with sacred spaces through incorporating pilgrimage studies in the curriculum was discussed. My own paper, "The Crossroads of Plastination and Pilgrimage", can be interpreted as a body donor's coming to terms with his mortality, something that may lead indirectly to the healing of others once this mortality occurs. Alison T. Smith emphasizes the mindfulness that a pilgrim should have for every step taken in "Walking Meditation: Being Present and Being Pilgrim" on the Camino de Santiago. It states how every step taken mindfully and peacefully is a step towards an inward reflection that will radiate into compassion for other pilgrims.

The diversity of viewpoints presented in this edition and the fact of their being contemporary can be of great significance to global readers, as they pave the way towards seeing pilgrimage not just as a religious tradition but also as a journey towards the healing and discovery of one's self. The papers in 
this Special Issue explore the different facets of pilgrimage from different scholarly perspectives so that readers can grasp its profound nature and the academic and pragmatic worth of upholding the value of pilgrimage for the array of purposes it serves, not just for pilgrims, but for everyone else.

Funding: The individual papers mentioned in this editorial were funded by the authors' respective institutions. The Sacred Journeys conference was funded by Indiana University Purdue University Indianapolis. This editorial received no external funding.

Conflicts of Interest: The author declares no conflict of interest.

(C) 2018 by the author. Licensee MDPI, Basel, Switzerland. This article is an open access article distributed under the terms and conditions of the Creative Commons Attribution (CC BY) license (http://creativecommons.org/licenses/by/4.0/). 